\title{
IMPLEMENTASI BIMBINGAN KEAGAMAAN PETUAH DALAM MENGANTISIPASI KENAKALAN REMAJA DI MADRASAH ALIYAH AR-ROSYIDIYAH KOTA BANDUNG
}

\author{
Apip Rudianto \\ UIN Sunan Gunung Djati Bandung \\ J1. A.H. Nasution 105 Cibiru, Bandung 40614, Indonesia. \\ E-mail: apip_rudianto@uinsgd.ac.id
}

\begin{abstract}
ABSTRAK
Penelitian ini berangkat dari pemikiran bahwa bimbingan keagamaan merupakan proses pemberian bantuan kepada seseorang yang mengalami kesulitan lahir maupun batin supaya dalam kehidupannya sejalan dengan ketentuan dan petunjuk Allah SWT. Untuk melakukan bimbingan keagamaan tersebut memerlukan suatu metode atau teknik yang tepat dan efektif dan dianggap baik ( $m a$ 'ruf), sejauh metode dan teknik tersebut tidak bertentangan dengan norma ajaran Islam. Lembaga pendidikan seperti Madrasah Aliyah merupak tempat dilangsungkannya pendidikan, melalui pendidikan di sekolah siswa di didik baik dari aspek akhlak, psikologis, maupun perilakunya terlebih pada sekolah berbasis keagamaan bahwa pola pendidikan akhlaknya sudah barang tentu menjadi prioritas utamanya. Namun fakta dilapangan menunjukan adanya beberapa bentuk kenakalan remaja baik bentuk kenakalan yang ringan hingga yang terberat. Oleh karena itu diperlukan program yang bertujuan untuk mengantisipasi kenakalan remaja tersebut, salah satunya melalui program bimbingan keagamaan petuah (pesantren sabtu ahad) yang ada di Madrasah Aliyah Ar-Rosyidiayah.
\end{abstract}

KATA KUNCI

Bimbingan Keagamaa;, Petuah; Kenakalan Remaja

DOI: https://doi.org/10.15575/saq.v2i1.2758

\section{A. PENDAHULUAN}

Masalah kenakalan remaja dewasa ini semakin dirasakan meresahkan masyarakat, baik di negara-negara maju maupun negaranegara yang sedang berkembang. Dalam kaitan ini, masyarakat Indonesia telah mulai pula merasakan keresahan tersebut, terutama mereka yang berdomisili di kota-kota besar. Akhir-akhir ini masalah tersebut cenderung menjadi masalah nasional yang dirasa semakin sulit untuk dihindari, ditanggulangi, dan diperbaiki kembali.

Setiap hari kita selalu disuguhi berita tentang tindakan amoral anak-anak dan remaja. Silih berganti televisi dan surat kabar memberitakan pemerkosaan yang korban maupun pelakunya siswa sekolah, mirasantika dikalangan remaja dan anak, tawuran antarsekolah, vandalism oleh siswa dan mahasiwa, pengeroyokan, aktivitas sex shop dan pecurian perampokan. Saat ini ada lebih dari 500 jenis video porno yang beredar, 90\% dibuat dan dilakukan oleh para remaja Indonesia yang masih berstatus remaja ujar Meutia Hatta (Jurnal Nasional, 10 April 2008 dalam Musfiroh 2008:25). 
Fenomena seperti itu ternyata banyak terjadi pada kalangan remaja. Secara psikologis, masa remaja merupakan masa yang begitu unik, penuh teka teki, dilematis dan sangat rentan. Unik karena pertumbuhannya banyak dipengaruhi oleh lingkungan sekitarnya sehingga karakter mereka berbeda-beda. Penuh teka-teki karena kepribadian mereka susah di tebak. Dilematis karena masanya merupakan peralihan dari masa anak-anak menuju usia dewasa sehingga cenderung coba-coba.

Deviasi atau penyimpangan diartikan sebagai tingkah laku yang menyimpang dari tendensi sentral atau ciri-ciri karakteristik ratarata dari rakyat kebanyakan/populasi. Sedang diferensiasi diartikan sebagai tingkah laku yang berbeda dari tingkah laku umum (Kartini Kartono, 2009:11). Suatu perilaku dikatakan menyimpang apabila perilaku tersebut dapat mengakibatkan kerugian terhadap diri sendiri dan orang lain.

Perilaku menyimpang cenderung mengakibatkan terjadinya pelanggaran terhadap norma-norma, aturan-aturan, nilainilai, dan bahkan hukum. Perilaku menyimpang disebut juga dengan tingkah laku bermasalah. Tingkah laku bermasalah masih dianggap wajar jika hal ini terjadi pada remaja. Maksudnya, tingkah lau ini masih terjadi dalam batas ciri-ciri pertumbuhan dan perkembangan sebagai akibat adanya perubahan secara fisik dan psikis.

Secara umum ciri-ciri dari remaja itu sendiri salah satunya adalah masa transisi dan masa pencarian identitas. Dalam hal perkembangan agama masa remaja berbeda dengan masa kanak kanak dan dewasa. Perkembangan agama pada usia remaja ditandai oleh beberapa faktor perkembangan jasmaniah maupun rohaniahnya, diantaranya: (1) pertumbuhan fikiran dan mental, (2) perkembangan perasaan, (3) pertimbangan sosial, dan (4) perkembangan moral. (W. Starbuck dalam Ramayulis Tuanku Khatib, 2002:57-61).

Salah satu metode yang bisa dikembangkan untuk mengembangkan perilaku keagamaan remaja agar terhindar dari perilaku penyimpangan remaja yaitu dengan metode bimbingan keagamaan. Dimana metode ini lebih menekankan kepada prilaku siswa mengenai wilayah keagamaan dan dalam pelaksanaanya bimbingan keagamaan ini bisa disesuaikan dengan kondisi siswa tersebut.

Bimbingan adalah seluruh program atau semua kegiatan dan layanan dalam lembaga pendidikan yang diarahkan pada membantu individu agar mereka dapat menyusun dan melaksanakan rencana serta melakukan penyesuaian diri dalam semua aspek kehidupannya sehari-hari (Tolbert dan Jonas dalam buku Sukmadinata, 2007:8).

Bimbingan merupakan suatu proses yang berkesinambungan sehingga bantuan itu diberikan secara sistematis, berencana, terusmenerus dan terarah dengan tujuan agar individu dapat mengembangkan dirinya secara optimal sesuai dengan potensi yang dimilikinya.

Salah satu program bimbingan keagamaan yang diterapkan di Madrasah Aliyah (MA) Ar-Rosyidiyah Kota Bandung yaitu bimbingan keagamaan petuah. Kata petuah sendiri berasal dari Bahasa Sunda yang berarti papatah (halus) ataum piwuruk (http://www.kamusbahasasunda.com/), adapun petuah yang dimaksud dalam program bimbingan keagamaan di Madrasah Aliyah (MA) yaitu pesantren sabtu ahad. Bimbingan ini dilaksanakan setiap minggunya yaitu pada hari sabtu malam ahad dengan tujuan untuk meminimalisir atau mengantisipasi kenakalan remaja, di lingkungan Madrasah Aliyah ArRosyidiyah Kota Bandung.

\section{B. RUMUSAN MASALAH}

Berdasarkan latar belakang yang dikemukakan di atas, pokok-pokok permasalahan secara umum pada penelitian ini adalah:

1). Seperti apakah bentuk kenakalan remaja di Madrasah Aliyah (MA) ArRosyidiyah Kota Bandung?

2). Bagaimana implementasi bimbingan keagamaan petuah dalam mengantisipasi kenakalan remaja di Madrasah Aliyah Ar-Rosyidiyah Kota 
Implementasi Bimbingan Keagamaan Petuah dalam

Mengantisipasi Kenakalan Remaja di Madrasah Aliyah

Ar-Rosyidiyah Kota Bandung

Bandung

\section{ASPEK TEORITIS BIMBINGAN KEAGAMAAN}

\section{1). Pengertian Bimbingan}

Secara harfiyah Pengertian bimbingan adalah "menunjukan, memberi jalan atau menuntun"orang lain kearah tujuan yang bermanfaat bagi hidupnya masa kini dan masa mendatang. Istilah bimbingan merupakan terjemah dari kata bahasa Inggris guidance yang berasal dari kata kerja "to guide" yang berarti menunjukan (H.M. Arifin, 1982:1).

Tohirin (2007:20) bimbingan bisa berarti bantuan yang diberikan oleh pembimbing kepada individu agar individu yang dibimbing mencapai kemandirian dengan mempergunakan berbagai bahan, melalui interksi, dan pemberian nasihat serta gagasan dalam suasana asuhan dan berdasarkan normanorma yang berlaku.

Selain itu bimbingan adalah seluruh program atau semua kegiatan dan layanan dalam lembaga pendidikan yang diarahkan pada membantu individu agar mereka dapat menyusun dan melaksanakan rencana serta melakukan penyesuaian diri dalam semua aspek kehidupannya sehari-hari. (Tolbert dan Jonas dalam buku Sukmadinata 2007:8).

Maka dapat diambil kesimpulan sementara dari beberapa definisi bimbingan sebagai berikut: Bimbingan merupakan suatu proses yang berkesinambungan sehingga bantuan itu diberikan secara sistematis, terencana, terusmenerus dan terarah dengan tujuan agar individu dapat mengembangkan dirinya secara optimal sesuai dengan potensi yang dimilikinya. Dengan demikian kegiatan bimbingan bukanlah kegiatan yang dilakukan secara kebetulan, insidental, sewaktu-waktu tidak sengaja atau kegiatan yang asal-asalan.

2). Pengertian Agama
Istilah Agama berasal dari bahasa Sansekerta yang tersusun dari, "a" artinya tidak dan "gam" tidak teratur, jadi penegrtian agama secara terminology artinya tidak kocar kacir atau jadi teratur (Sudarsono, 2008:118).

Mengenai definisi agama sebenarnya sudah banyak sarjana yang merumuskannya, namun satu sama lain ada segi kesamaannya. Franz Dahler dalam Sudarsono (2008:118) membuat batasan atau definisi umum tentang agama sebagai berikut: agama adalah hubungan manusia dengan suatu kekuatan suci yang lebih tinggi dari pada dia, dari mana ia merasa tergantung dan berusaha mendekatinya.

\section{ASPEK TEORITIS PETUAH}

Berdasarkan hasil wawancara dengan guru BK dan guru pembimbing keagamaan petuah bahwa kata petuah merupakan sebuah kegiatan dari suatu program bimbingan keagamaan yang ada di sekolah. Kata petuah merupakan singkatan dari Pesantren sabtu ahad.

Bimbingan keagamaan petuah ini merupakan salah satu program bimbingan keagamaan yang diterapkan di Madrasah Aliyah. Bimbingan keagamaan ini difokuskan bagi siswa-siwi dengan metode yang diterapkan dalam bimbingan tersebut yaitu berupa ceramah, diskusi ataupun mentoring. Materi-materi yang diberikan yaitu berupa materi yang berhubungan dengan akhlak, dan tauhid,

Bimbingan ini dilaksanakan setiap minggunya yaitu pada hari sabtu malam minggu dengan di bimbing oleh seorang guru pembimbing. Bimbingan ini dilaksankan dari jam 17.00 WIB sampai dengan jam 06.00 WIB pagi pada hari minggunya.

Kegiatan ini diawali dengan sambutan dari kepala sekolah dilanjutkan dengan shalat maghrib dan isya berjamaah lalu dilanjutkan dengan pemberian materi yang menyangkut aspek akhlak, tauhid serta intensifikasi mata pelajaran yang akan di-UN-kan dengan menggunakan metode ceramah, diskusi serta 
mentoring kelompok.

Jam 02.00 siswa dibangunkan untuk melaksanakan shalat tahajud dan dilanjutkan dengan tausiah dan baca Al-Qur'an sampai dengan waktu subuh. Salah satu tujuan dari bimbingan keagamaan petuah ini yaitu untuk meminimalisir atau mengantisipasi kenakalan remaja yang terjadi dikalangan siswa-siswi serta untuk membiasakan diri untuk belajar mandiri dan untuk membiasakan diri bangun malam untuk shalat tahajud.

\section{E. ASPEK TEORITIS BIMBINGAN KEAGAMAAN PETUAH}

Menurut H.M. Arifin (1982:2) pengertian bimbingan keagamaan dapat diartikan sebagai usaha pemberian bantuan kepada seseorang yang mengalami kesulitan baik lahiriah maupun batiniah yang menyangkut kehidupannya dimasa kini dan masa mendatang. Bantuan tersebut berupa pertolongan dibidang mental dan spiritual, agar orang yang bersangkutan mampu mengatasinya dengan kemampuan yang ada pada dirinya sendiri melalui dorongan dari kekuatan iman dan taqwanya kepada Tuhannya.

Kemudian menurut Aunur Rahim Faqih (2001:62) bimbingan keagamaan Islami dapat diartikan sebagai proses pemberian bantuan terhadap individu agar kehidupan keagamaannya senantiasa selaras dengan ketentuan dan petunjuk Allah SWT sehingga dapat mencapai kebahagiaan hidup di dunia dan akhirat.

Sasaran bimbingan keagamaan adalah membangkitkan daya rohaniah manusia melalui iman dan ketaqwaannya kepada Allah SWT untuk mengatasi segala kesulitan hidup yang dialaminya. Jadi iman dan taqwanya dibangkitkan sedemikian rupa sehingga dapat menjadi tenaga pendorong terhadap kemampuan dirinya untuk mengatasi segala kesulitan hidup yang dihadapinya.

Oleh karena itu pengertian bimbingan keagamaan petuah adalah suatu proses pemberian bantuan secara terus menerus atau berkesinambungan kepada individu yang memerlukan bantuan dalam memecahkan masalah, terutama pemecahan masalah dalam menghadapi kesulitan-kesulitan rohaniyah dalam lingkungan hidupnya agar dalam kehidupan keagamaannya senantiasa selaras dan seimbang dengan petunjuk dan ketentuan Allah SWT dengan menggunakan metodemetode seperti ceramah, diskusi dan mentoring sehingga dapat mencapai kebahagiaan hidup di dunia dan akhirat.

\section{F. ASPEK TEORITIS KENAKALAN REMAJA (JUVENILE DELINQUENCY)}

\section{Bimo Walgito dalam Sudarsono} (2008:11) menjelaskan bahwa Juvenile delinquency adalah tiap perbuatan, jika perbuatan tersebut dilakukan oleh seorang dewasa, maka perbuatan itu merupakan kejahatan, jadi merupakan perbuatan yang melawan hukum, yang dilakukan oleh anak, khususnya anak remaja.

Pengertian lain mengatakan bahwa Juvenile delinquency adalah suatu perbuatan yang melanggar norma, aturan atau hukum dalam masyarakat yang dilakukan pada usia remaja atau transisi masa anak-anak dan dewas (Kartini Kartono, 1986:7).

Menurut Kartini Kartono (1986:21) wujud perilaku delinkuen dibagi menjadi:

1). Kebut-kebutan dijalanan yang menganggu keamanan lalu lintas, dan membahayakan jiwa sendiri serta orang lain.

2). Perilaku ugal-ugalan, berandalan, urakan yang mengacaukan ketentraman milieu sekitar. Tingkah ini bersumber pada kelebihan energi dan dorongan primitiv yang tidak terkendali serta kesukaran menteror lingkungan.

3). Perkelahian antar gang, antarkelompok, antarsekolah, antarsuku (tawuran), sehingga kadang-kadang membawa korban jiwa.

4). Membolos sekolah lalu bergelandangan sepanjang jalan, atau bersembunyi di tempat-tempat terpencil sambil melakukan eksperimen bermacam-macam kedurjanaan dan tindak a-susila. 
Implementasi Bimbingan Keagamaan Petuah dalam

Mengantisipasi Kenakalan Remaja di Madrasah Aliyah

Ar-Rosyidiyah Kota Bandung

5). Kriminalitas anak, remaja dan adolesens antara lain berupa perbuatan mengancam, intimidasi, memeras, mencuri, dll.

6). Berpesta pora, sambil mabuk-mabukan, dan melakukan hubungan seks bebas.

7). Perkosaan, agresivitas seksual, dan pembunuhan dengan motif seksual, atau didorong oleh reaksi-reaksi kompensators dari perasaan inferior, dll.

8). Kecanduan dan ketagihan bahan narkotika (obat bius, drugs) yang erat bergandengan dengan tindak kejahatan.

9). Tindak-tindak immoral seksual secara terang-terangan, tanpa tending aling-aling, tanpa rasa malu dengan cara yang kasar. Ada seks dan cinta bebas tanpa kenali yang didorong oleh hiperseksualitas geltungsrieb (dorongan menuntut hak) dan usaha-usaha konpensasi lainnya yang kriminal sifatnya.

10). Homoseksualitas, erotisme anal dan oral dan gangguan seksual lain pada anak remaja disertai tindakan-tindakan sadistis.

11). Perjudian dan bentuk-bantuk permainan lain dengan taruhan, sehingga mengakibatkan ekses kriminal.

\section{G. METODE PENELITIAN}

Metode penelitian yang digunakan adalah metode deskriptif, yang mencoba memaparkan situasi atau peristiwa dan tidak mencoba untuk mencari atau menjelaskan hubungan, tidak menguji hipotesis atau membuat prediksi (Jalaludin Rahmat, 1999:24).

Sedangkan menurut Sudarwan Danim (2002:41) penelitian deskriptif dapat diartikan sebagai penelitian yang dimaksudkan untuk memotret fenomena individual, situasi, atau kelompok tertentu yang terjadi secara kekinian. Dengan kata lain, tujuan penelitian deskriptif adalah mendeskripsikan seperangkat peristiwa atau kondisi populasi saat ini.

Lebih lanjutnya, metode deskriptif ditujukan untuk:
1). Mengumpulkan informasi aktual secara rinci untuk melukiskan gejala yang ada.

2). Mengidentifikasi masalah atau memeriksa kondisi dan praktek-praktek yang berlaku.

3). Membuat perbandingan atau evaluasi.

4). Menentukan apa yang dilakukan orang lain dalam menghadapi masalah yang sama dan belajar dari pengalaman mereka untuk menetapkan rencana dan keputusan pada waktu yang akan datang.

Relevansinya dengan penelitian ini, dimaksudkan untuk menggambarkan atau memaparkan suatu keadaan serta menguraikan permasalahan yang menjadi objek penelitian, dan bagaiman langkah-langkah yanga diambil untuk mengantisipasi kenakalan remaja di Madrasah Aliayah Ar-Rosidiyah.

\section{H. TEKNIK PENGUMPULAN DATA}

Adapun teknik yang digunakan untuk menghimpun dan mengumpulkan data yang relevan dengan penelitian ini adalah:

\section{1). Observasi}

Observasi diartikan sebagai suatu cara untuk mengadakan penelitian dengan jalan mengadakan pengamatan dan pencatatan secara sistematis terhadap gejala yang diteliti. Penelitian ini menggunakan teknik observasi non participant, dimana peneliti tidak sepenuhnya melakukan "intervensi" tetapi hanya melakukan pengamatan (Jalaludin Rahmat, 1999:85).

Observasi pada penelitian ini dilakukan untuk melihat proses perencanaan program bimbingan keagamaan petuah dan implementasi program bimbingan keagamaan petuah dalam mengantisipasi kenakalan ramaja di Madrasah Aliyah Ar-Rosyidiyah. Melalui observasi ini diharapkan penulis dapat memperoleh berbagai data yang tidak didapatkan melalui wawancara.

2). Wawancara 
Wawancara dalam penelitian merupakan salah satu dari sejumlah metode pengumpulan data yang dapat digunakan untuk memperoleh informasi yang diperlukan. Dilihat dari proses pengumpulan datanya, wawancara dapat disebut "seni menanyakan sesuatu dengan 'alat' pertanyaan yang benar" (Asep Saeful Muhtadi, 2005:161).

Selain itu menurut Sudarwan Danim (2002:130) wawancara adalah sebuah percakapan antara dua orang atau lebih, yang pertanyaannya diajukan oleh peniliti kepada subjek atau sekelompok subjek penelitian untuk dijawab.

Wawancara pada penelitian ini akan dilakukan terhadap kepala sekolah Madrasah Aliyah Ar-Rosyidiyah, guru BK Madrasah Aliyah Ar-Rosyidiyah, dan para pembimbing keagamaan petuah Madrasah Aliyah ArRosyidiyah. Wawancara bertujuan untuk menggali berbagai informasi tentang jenis-jenis kenakalan remaja, faktor-faktor penyebab kenakalan remaja, rancangan program bimbingan keagamaan petuah dalam mengantisipasi kenakalan remaja di MA ArRosyidiyah, dan bagaimana implementasi program petuah tersebut di lapangan.

\section{3). Dokumentasi}

Dokumentasi adalah pelengkap dari penggunaan metode observasi dan wawancara dalam penelitian kualitatif, teknik ini juga digunakan untuk mengetahui data-data tertulis mengenai MA Ar-Rosyidiyah dengan cara menyusuri berbagai dokumen, arsip, foto, atau buku-buku yang berkaitan dengan penelitian (Lexy Moleong, 2007:217-218).

Dokumentasi dalam penelitian ini adalah pendukung secara visual tentang kejadian selama penelitian berlangsung. Dokumentasi dilakukan dengan pengumpulan data-data tertulis, berkas-berkas, dan keadaan lingkungan di MA Ar-Rosyidiyah.

\section{HASIL PENELITIAN}

\section{Bentuk-Bentuk Kenakalan Remaja di Madrasah Aliyah (MA) Ar-Rosyidiyah.}

Berdasarkan hasil penelitian di MA Ar-Rosyidiyah dan dari hasil wawancara terhadap kepala sekolah, guru BP, pembimbing petuah, dan guru serta stap TU MA Ar-Rosyidiyah bahwa di sekolah tersebut masih ada beberapa bentuk-bentuk kenakalan remaja yang terjadi disana, baik bentuk kenakalan yang sifatnya ringan hingga yang terberat.

Hasil wawancara peneliti dengan Bapak kepala sekolah Bapak Agus Rahmat bahwa bentuk kenakalan remaja yang terjadi di kalangan remaja itu sifatnya wajar dan alami karena secara perkembangan psikologis, masa remaja merupakan masa pencarian indentitas atau jati diri, namun dalam realitas perkembangannya remaja tersebut sering melakukan hal-hal yang diluar batas kewajaran sehingga menimbulkan bentuk-bentuk kenakalan yang terjadi pada saat sekarang walaupun mungkin tidak semua remaja seperti itu.

Secara umum bentuk kenakalan remaja yang terjadi di MA Ar-Rosyidiyah yang di dapat dari hasil wawancara dengan Bapak kepala sekolah yaitu ada bentuk kenakalan yang terjadi di sini, bahkan setiap tahunnya itu bisa dikatakan naik ataupun turun angka kenakalannya. Dalam hal ini kenakalan yang terjadi dikalangan siswa itu masih dianggap wajar walaupun ada bentuk kenakalan remaja yang berat yang terjadi disini. Menurut Bapak kepala sekolah kenakalan yang terjadi di MA Ar-Rosyidiyah ini meliputi bentuk-bentuk kenakalan yang sifatnya masih dalam batas perkembangan remaja, tapi kalau sepertinya kenakalan tersebut sudah diluar batas kewajaran bahkan menjurus kepada tindakan kiriminal maka pihak sekolah akan memberikan sangsi yang tegas kepada siapa saja yang melanggarnya bahkan bisa saja di keluarkan dari sekolah karena semuanya itu sudah ada tata tertib yang di buat oleh pihak sekolah sampai kepada bentuk sangsi yang 
Implementasi Bimbingan Keagamaan Petuah dalam

Mengantisipasi Kenakalan Remaja di Madrasah Aliyah

Ar-Rosyidiyah Kota Bandung

diterimanya (hasil wawancara dengan Kepala Sekolah Bapak Agus Rahmat, tanggal 30 April 2012).

Ditambahkannya bahwa bentuk pelanggaran yang terjadi itu sebagian besar terjadi diluar lingkungan sekolah. Menurut beliau bentuk kenakalan remaja yang terjadi diluar lingkungan sekolah diantaranya: berkelahi, tawuran, geng-gengan dan mabuk. Secara umum bahwa bentuk kenakalan masih dianggap ringan dan biasa terjadi di sini diantaranya ada kasus sering bolos, bullying, merokok. Sedangkan kasus kenakalan remaja yang dianggap berat adalah geng motor, narkoba, dan pergaulan bebas (hasil wawancara dengan Kepala Sekolah Bapak Agus Rahmat, 30 April 2012).

Sementara itu, hasil dari wawancara dengan guru pembimbingan petuah Bapak Hendra pada tanggal 25 April 2012 mengenai bentuk kenakalan remaja yang terjadi di MA Ar-Rosyidiyah adalah bahwa bentuk kenakalan itu lebih di fokuskan ke dalam pelaksanaan petuah, maksudnya pelanggaran yang dilakukan oleh siswa itu di lakukan ketika bimbingan petuah. Tapi secara umum bahwa bentuk kenakalan remaja yang terjadi di sini hampir sama pemaparannya dengan apa yang di utarakan oleh Bapak Kepala Sekolah.

Dalam pelaksanaan bimbingan petuah pelanggaran yang terjadi di kalangan siswa diantaranya, datang dengan seenaknya tanpa konfirmasi terlebih dahulu, suka membolos maksudnya dari rumahnya berangkat tapi ke sekolahnya tidak ada, suka menulis surat izin atau sakit suka di buatin sama temennya dan suka kabur ketika jam pelajaran. Sementara bentuk kenakalan yang terjadi secara umum yaitu suka merokok di luar sekolah tapi masih berpakaian seragam sekolah dan absensi. Berkaitan dengan hal tersebut maka menurut pembimbing petuah harus ada bentuk sangsi atau pembinaan yang diberikan kepada para siswa yang melanggar peraturan khusunya dalam bentuk kegiatan petuah, adapun bentuk sangsi atau pembinaan yang diberikan kepada siswa yang melanggar adalah di beri tugas menulis surat yang ada di Al-Qur'an itu setiap satu kali tidak mengikuti kegiatan pada
Apip Rudianto

bimbingan petuah serta sangsi akademik, maksudnya akan berpengaruh terhadap nilai praktek ibadah pada mata pelajaran PAI (hasil wawancara kepada pembimbing petuah Bapak Erlan Suherlan, 01 Mei 2012).

Sementara itu menurut hasil observasi dan wawancara terhadap guru BK mengenai bentuk kenakalan remaja bahwa bentuk kenakalan yang terjadi disini sifatnya wajar tidak ada bentuk kenakalan yang sifatnya berat untuk tahun sekarang, tapi dalam beberapa tahun ke belakang ada beberapa bentuk kenakalan remaja yang terjadi di sekolah ini. Senada dengan pernyataan guru BK bidang kesiswaan juga berpendapat bahwa bentuk kenakan remaja yang terjadi di sini sifatnya masih dalam bentuk batas kewajaran meskipun ada hal-hal yang dianggap sedikit melanggar tata tertib (untuk lebih jelasnya tata tertib sekolah bisa dilihat di lampiran) sekolah dan biasanya bentuk kenakalan remaja lebih banyak di lakukan oleh siswa kelas XI (hasil wawancara dengan guru BK (Ibu Ivo) dan kesiswaan (Ibu Nenden) pada tanggal 30 April 2012).

Dalam penanganan pelanggaran yang terjadi di sekolah pihak BK bekerja sama dengan kesiswaan untuk menanganinya dan proses penanganannya ada beberapa tahapan, diantaranya pertama guru BK memanggil siswa yang bersangkutan untuk dinasehati dan menandatangani surat perjanjian. Kedua, guru BK memanggil orang tua yang berasangkutan agar orang tua tahu sifat anaknya dan memberikan nasihat kepada orang tua agar di nasihati anaknya. Ketiga, apabila anak masih melakukan pelanggaran tersebut maka guru BK dan Kesiswaan yang bekerja sama dengan Kepala Sekolah akan mengeluarkan anak yang bermasalah tersebut (hasil wawancara dengan guru BK Ibu Ivo pada tanggal 25 April 2012).

Data yang diperoleh dari buku catatan kasus yang ada di guru BK bahwa bentuk kenakalan remaja yang terjadi di MA ArRosyidiyah pada tahun pelajaran 2010/2011 bisa dikatakan beragam sekali jenis dan bentuknya. 


\section{Implementasi bimbingan keagamaan petuah dalam mengantisipasi kenakalan remaja di Madrasah Aliyah (MA) Ar- Rosyidiyah.}

Hasil wawancara dan observasi terhadap pelaksanaan bimbingan petuah yang ada di MA Ar-Rosyidiyah itu secara umum sudah terprogramkan dengan baik dari mulai awal kegiatan bimbingan petuah sampai ke akhir kegiatannya. Selain hal itu juga program petuah ini sudah mempunyai buku panduan bimbingan petuah yang dibuat oleh para pembimbing petuah agar dalam penyampaian materi dari setiap pertemuannya sesuai dengan silabus yang telah ditentukan oleh pembimbing.

Program petuah ini dilaksanakan selama dua hari yaitu hari sabtu dan minggu dalam setiap minggunya selama tahun. Selama satu tahun itu program petuah dilaksanakan oleh dua orang pembina bimbingan petuah yaitu Pak Erlan Suherlan dan Pak Hendra.

Materi-materi yang diberikan dalam proses petuah lebih banyak kepada materi yang membahas tentang akhlak dan keagaman serta materi-materi penunjang lainnya yang sifatnya itu lagi hangat-hangat dibicarakan. Dalam pelaksanaannya program ini terbagi menjadi dua, yaitu program semester ganjil dan program semester genap.

Program semester ganjil itu semua siswa dilibatkan mulai dari kelas X, XI dan XII dengan sistem pelaksanaannya itu di rolling setiap minggunya dan untuk program petuah pada semester genap itu lebih di wajibkan kepada siswa kelas XII karena disamping pemberian materi-materi keagamaan, dan program ini juga di khususkan sebagai program pemantapan mata pelajarana yang akan di UN kan serta sebagai wahana pelaksanaan ujian praktek ibadah dalam mata pelajaran PAI sehingga tidak repot lagi mencari waktu untuk melaksanakan ujian tersebut (wawancara dengan Pembimbing Petuah Bapak Erlan Suherlan dan Pak Hendra tanggal 24 April 2012).

Dalam proses pelaksanaan bimbingan petuah ada beberapa kegiatan yang dibuat oleh pembimbing petuah dan harus di ikuti oleh para siswa. Kegiatan tersebut sudah mencakup semua proses petuah mulai dari absensi hingga ke kuliah subuh di keesokan harinya. Di bawah ini merupakan jadwal pelaksanaan bimbingan petuah yang dilaksanakan setiap minggunya.

Jenis kegiatan yang dilaksanakan pada proses pelaksanaan bimbingan keagamaan petuah, diantaranya:

\section{a. Cheking Peserta dan Pengarahan}

Kegiatan ini dilaksanakan pada awal kegiatan petuah, biasanya cheking peserta dilaksanakan jam 17.00-17.30 WIB. Dalam kegiatan tersebut pembimbing petuah mengabsen siswa untuk satu kali kegiatan, jadi dalam setiap kegiatan itu ada absensinya masing-masing. Proses cheking peserta ini di fokuskan di ruangan kelas atau di mesjid sekolah. Selain itu pembimbing petuah juga menyampaikan pengumuman terkait dalam pelaksanaan petuah pada pertemuan itu. Contohnya menyampaikan materi yang akan didiskusikan atau pengumuman lainnya.

\section{b. Sholat Maghrib Berjama'ah}

Kegiatan ini dilaksanakan pada jam shalat maghrib di mesjid sekolah Al-Manami. Siswa yang mengikuti bimbingan petuah ini di wajibkan untuk ikut shalat berjama'ah shalat magrib karena ada perbedaan penilaian tersendiri kepada siswa bagi yang ikut shalat berjama'ah dan tidak.

\section{Pengarahan dari Kepala Madrasah}

Pengarahan itu sendiri biasanya di sampaikan oleh Bapak kepala sekolah ataupun oleh pembimbing petuah. Biasanya isi dari pengarahan itu sendiri berisi pengumuman ataupun mengulas kembali materi-materi yang sudah disampaikan pada minggu yang lalu. Selain itu juga ada berupa tausiyah-tausiyah dari kepala sekolah atau pembimbing petuah.

\section{c. Sholat 'Isya Berjama'ah}

Kegiatan ini dilaksanakan pada jam shalat Isya di mesjid Al-Manami. Siswa yang mengikuti bimbingan petuah ini di wajibkan 
Implementasi Bimbingan Keagamaan Petuah dalam Mengantisipasi Kenakalan Remaja di Madrasah Aliyah Ar-Rosyidiyah Kota Bandung

untuk ikut shalat berjama'ah shalat isya karena ada perbedaan penilaian tersendiri kepada siswa bagi yang ikut shalat berjama'ah dan tidak.

\section{d. Mengaji bersama}

Kegiatan ini dilaksanakan setelah shalat isya berjama'ah. Sebelum ngaji bersama pembimbing petuah mengabsen kembali siswa yang ikut kegiatan ngaji bersama. Tujuan dari kegiatan ini supaya siswa terbiasa untuk mengaji Al-Qur'an dan melihat kemampuan siswa dalam BTQ. Siswa diwajibkan untuk membawa Al-Qur'an pada setiap minggunya dan kegiatan ngaji bersama ini di fokuskan di ruangan kelas dan di pandu oleh pembimbing petuah. Biasanya surat yang di baca yaitu surat Yassin, tapi dalam setiap minggunya juga suka dijadwalkan surat apa yang akan dibaca pada setiap minggunya.

\section{e. Penyampaian materi dan diskusi kelompok}

Kegiatan ini dilaksanakan dari jam 20.3022.00 WIB. Kegiatan ini juga merupakan salah satu kegiatan inti dalam proses pelaksanaan petuah karena pada kegiatan ini pembimbing petuah akan menyampaikan meteri-materi yang dibutuhkan oleh siswa ataupun materi yang lagi hangat di bicarakan dan selanjutnya materi tersebut akan di diskusikan oleh siswa. Adapun materi yang telah disampaikan pada waktu bimbingan petuah diantaranya: etika terhadap orang tua, motivasi mencapai citacita, Tips dan Trik Menghadapi UN, serta materi tentang Pengurusan Jenazah dan lainlain (untuk lebih jelasnya mengenai materimateri yang telah disampaikan dalam bimbingan petuah, bisa dilihat di lampiran). Selain meteri-materi diberikan kepada siswa, dalam pelaksanaan petuah juga diberikan berupa hapalan-hapalan do'a-d'oa baik itu shalat wajib maupun shalat sunat.

Setelah materi tersebut disampaikan oleh pembimbing petuah, maka siswa akan di bagi menjadi beberapa kelompok untuk berdiskusi mengenai materi yang tadi telah di sampaikan sehingga nanti hasil diskusi tersebut dari setiap kelompok akan di persentasikan oleh perwakilan dari setiap kelompoknya dan kelompok yang lain juga bisa menanggapi hasil diskusi dari kelompok lainnya. Sehingga diharapkan mendapatkan sebuah kesimpulan sementara mengenai materi tersebut.

\section{f. Tahajjud dan Tadarrus}

Kegiatan ini dilaksanakan sekitar jam 03.00 WIB untuk melaksanakan shalat sunat tahajjud di mesjid Al-Manami. Semua peserta wajib ikut dalam pelaksanaan kegiatan ini karena pada setiap kegiatannya itu di absen dan akan berpengaruh kepada nilai petuah. Setelah shalat tahajjud selesai maka peserta di wajibkan untuk melaksanakan kegiatan tadarrus bersama-sama di mesjid Al-Manami.

Dalam pelaksanaan tadarrus siswa di bebaskan untuk membaca surat dalam Al-Quran karena kegiatan ini merupakan jeda dari shalat tahajjud dan sambil menunggu waktu shalat shubuh.

\section{g. Sholat Shubuh Berjama'ah}

Setelah kegiatan shalat tahajjud dan tadarrus maka selanjutnya dilanjutkan dengan shalat shubuh berjama'ah di mesjid AlManami. Lalu setelah itu pembimbing petuah mengabsen kembali setelah shalat shubuh untuk mengetahui siapa saja yang melaksankan shalat berjama'ah dan yang tidak.

\section{h. Ujian Praktek Ibadah dan Hafalan}

Kegiatan ini dimulai setelah kegiatan shalat shubuh berjama'ah sampai jam 06.30. kegiatan ini juga merupakan salah satu inti dari kegiatan petuah karena selain menyampaikan berbagai materi petuah juga sebagai wahana ujian praktek ibadah mata pelajaran PAI dan ditambah hapalan berbagai do'a-do'a. kegiatan ini di fokuskan di ruangan kelas dan di uji oleh pembimbing petuah yaitu Pak Erlan dan Pak Hendra. Dalam ujian praktek tersebut biasanya ada kriteria-kriteria khusus dalam ujian praktek ibadah sehingga menjadi acuan dalam penilaian ujian praktek ibadah tersebut.

Setelah selesai ujian praktek ibadah maka selanjutnya yaitu setoran hapalan surat-surat serta do'a-do'a yang semuanya itu sudah di 
tentukan oleh para pembimbing petuah dan do'a-do'a tersebut juga sudah di rangkum dalam bentuk buku panduan bimbingan petuah.

\section{i. Clean Up Room Together}

Setelah selesai semuanya dari kegiatan awal sampai akhir maka kegiatan selanjutnya yaitu beres-beres dan bersih-bersih di tempat kegiatan petuah yaitu di mesjid dan di kelas. Siswa dibagi menjadi beberapa kelompok untuk membersihkan semua tempat-tempat tersebut. Selanjutnya pembimbing petuah memberikan sedikit ceramah mengenai penilaian pelaksanaan program kegiatan petuah dan terakhir biasanya pembimbing petuah mengumumkan siapa saja yang tidak ikut melaksanakan salah satu kegiatan pada saat petuah dan bisanya siswa tersebut di wajibkan untuk menulis surat yang ada di Al-Qur'an.

\section{J. KESIMPULAN}

Hasil penelitian yang didapatkan oleh peneliti bahwa proses pelaksanaan bimbingan petuah sudah optimal, hal ini dikarenakan pihak sekolah yang berkerja sama dengan pembimbing petuah dalam membuat perencanaan program patuah yang bisa dikatakan sesuai dengan pelaksanaan petuah. Hal yang paling penting dengan adanya bimbingan keagamaan petuah ini dapat meminimalisir angka kenakalan ramaja yang terjadi di sekolah.

Secara umum bentuk-bentuk kenakalan remaja yang terjadi di sekolah MA ArRosyidiyah itu beragam bentuk dan jenisnya, tapi masih dalam batas kewajaran sesuai dengan perkembangan remaja bukan kepada bentuk kenakalan yang menjurus ke tindakan kriminalitas. Bentuk kenakalan yang sering terjadi di sana yaitu bolos dan minggat dari sekolah sedangkan bentuk kenakalan yang bisa dikatakan berat yang pernah terjadi disini yaitu merokok,berkelahi,dan miras tapi semua bentuk kenakalan tersebut terjadi diluar lingkungan sekolah.

Implementasi bimbingan keagamaan petuah MA Ar-rosyidiyah dalam mengantisipasi kenakalan remaja dilaksanakan setiap minggunya yaitu pada hari sabtu dan hari minggu. Program petuah ini di awali dengan: Cheking Peserta dan Pengarahan, Sholat Maghrib Berjama'ah, Pengarahan dari Kepala Madrasah, Sholat 'Isya Berjama'ah, Mengaji bersama, Penyampaian materi dan diskusi kelompok, Istirahat, Tahajjud dan Tadarrus, Sholat Shubuh Berjama'ah, Ujian Praktek Ibadah dan Hafalan, dan Clean Up Room Together. Berdasarkan temuan penelitian menunjukan bahwa dalam segi implementasi program bimbingan petuah, kendala yang ditemukan yaitu mengenai materi petuah dan kehadiran peserta.

\section{K. DAFTAR PUSTAKA}

Arifin, H.M. (1982). Pedoman Pelaksanaan Bimbingan dan Penyuluhan Islam. Golden Terayon, Jakarta.

Danim, Sudarwan. (2002). Menjadi Peneliti Kualitatif. Pustaka Setia, Bandung

Faqih, Aunur Rahim. (2001). Bimbingan dan Konseling dalam Islam. UII Press, Yogyakarta

Kartono, Kartini. (1968). Patologi Sosial 2 Kenakalan Remaja. Rajawali, Jakarta.

Kartono, Kartini. (2009). Patologi Sosial 1. Rajawali, Jakarta..

Khatib, Ramayulis Tuanku. (2002). Psikologi Agama. Kalam Mulia, Jakarta.

Moleong, Lexy. (2007). Metodologi Penelitian Kualitatif. PT. Remaja Rosdakarya, Bandung.

Muhtadi, Asep Saeful. (2005). Metode Penelitian Dakwah. Pustaka Setia, Bandung.

Musfiroh, Tadkiroatun. (2008). Tinjauan Berbagai Aspek Character Building. Tiara Wacana, Yogyakarta.

Nurihsan, Achmad Juntika. (2009). Bimbingan dan Konseling dalam Berbagai Latar Kehidupan. Refika Aditama, Bandung.

Rakhmat, Jalaludin. (1997). Metode Penelitian Komunikasi. PT. Remaja Rosda Karya, Bandung.

Sudarsono. (2008). Kenakalan Remaja. Rineka Cipta, Jakarta.

Sukmadinata, Nana Syaodih.(2007). Bimbingan dan Konseling dalam Paraktek. 
Maestro, Jakarta.

Tohirin. (2007). Bimbingan dan Konseling di

Sekolah dan Madrasah (berbasis integrasi).

PT. Raja Grafindo Persada, Jakarta.

http://www.kamusbahasasunda.com/ 